\title{
Quality Education And The Impact Of Public And Independent Schools Writing The National Senior Certificate Examination In South Africa
}

\author{
Nelda Mouton, North-West University, South Africa
}

Gert L. Strydom, North-West University, South Africa

\begin{abstract}
A new education curriculum for a new democratic dispensation was welcomed and unavoidable in South Africa after the first democratic election in 1994. The main reason for this radical change within education was that policymakers needed to move away from the apartheid curriculum with all its attendant political baggage and address the laudable outcomes of skills, knowledge and values for purposes of achieving social justice, equality and development. Within this curriculum, the South African Schools' Act (Act 84 of 1996) recognises two broad categories of schools public and independent schools. All public schools follow the National Curriculum Statement (NCS) and independent schools have the freedom to choose which curriculum and which examination body they want their learners to write, as long as the examining body is recognised by Umalusi.
\end{abstract}

This article will reflect on the quality of education provided in schools by analysing the roles and impact of public and independent schools writing the National Senior Certificate in South Africa. It is important, in this context, to provide a historical overview of the background of examination bodies that have impacted on the South African school system. It is also deemed necessary to reflect on and discuss the public and independent school sector by focussing on factors influencing the logistical orientation of these sectors as well as reflecting on indicators influencing the Grade 12 examination. After analysing these factors and reflecting on issues that influence quality education in South Africa, recommendations will be made in an effort to contribute to the improvement of the standard of education in South Africa.

Keywords: Public Schools; Independent Schools; Umalusi; Benchmarking; Quality Education

\section{INTRODUCTION}

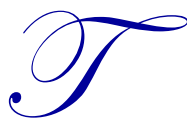

he political thinking in 1994 was to abolish all the old that had been systemically linked with apartheid and to introduce new policies in all the various spheres in the country, as schooling had been perceived to have been in dire straits for many years (Du Plessis, 2009). Since the amalgamation of the eighteen different ex-departments of education in South Africa, great discrepancies in the quality of teaching, learner responses, classroom method, and assessment had become increasingly obvious - the unavoidable conclusion was that learners were not learning what they were supposed to learn (Coetzee \& Johl, 2008). Although many previous systems had been excellent (even though they might have had flaws and room for improvement), it was imperative that within the ideological construct known as the new South Africa, instead of assessing what was good and building on that, the new approach - or OBE (Outcomes Based Education) - was to discard tried and tested basic principles of education in favour of effecting a sweeping and complete revamping of the South African education landscape (Mouton, Louw \& Strydom, 2012). 
Thus, a new curriculum for a new dispensation was welcomed and unavoidable, but the bottom line was that diverse cultures, extreme backgrounds of learners, values in education, and so forth, had to be taken into account, and Curriculum 2005 (generally referred to as OBE) was introduced (Mouton et al., 2012). It was inevitable that many shortcomings in the curriculum would emerge, and these proliferated as implementation was almost impossible because of factors associated with expense and poor preparation of teachers for a complex and demanding new way of teaching. Learners therefore suffered from the outset (Malada, 2010).

Another reason for this radical change within education was that policymakers wanted to move away from the apartheid curriculum and address the doubtlessly laudable outcomes of skills, knowledge and values for social justice, equality and development (Spreen \& Vally, 2010) as propagated by OBE. In this regard, Harley and Wedekind (2004) felt that the ensuing change in the form of Curriculum 2005 (C2005) was of a scale arguably unparalleled in the history of curriculum change. Thus, it could be assumed that a new approach to education would be a useful tool for changing many of the obsolete approaches, such as rote-learning and learning merely to pass, which were considered devoid of any holistic content (Nair, 2003); but the negative impact, which had been largely unanticipated, would militate against the achievement of the positive outcomes so desperately envisaged.

Various implementation problems of C2005 led to the implementation of the Revised National Curriculum Statements (RNCS) in 2008 after a review had been done (Matoti, 2010). Problems persisted and the Minister of Basic Education, Angie Motshekga, announced a new curriculum improvement process on 6 July, 2010, and once again radical changes for the curriculum were planned for the period from 2012-2014 (Maluleka, 2011). This onceagain revised curriculum (to be referred to as the CAPS [Curriculum and Assessment Policy Statements], Maluleka, 2011) holds its own challenges. This revision is intended to strengthen the NCS (National Curriculum Statements) in order to improve the quality of teaching and learning in schools (Mouton et al., 2012).

As from 2008, South African Grade 12 school learners wrote the National Senior Certificate examinations for the first time (Mouton et al., 2012). The NCS offers 29 subjects at one level. Consequently, there is no distinction between subjects at the higher, standard or lower grades (Nel \& Kistner, 2009).

On the other hand, the Independent Examinations Board (or IEB) is a South African independent assessment agency which offers examinations for client schools. It is most prominent in setting the examinations for the school-leaving National Senior Certificate (Wikepedia, 2013). In South Africa, an independent school has the freedom to choose which examining body's examinations it wants to write provided that the body is recognised by Umalusi (The Council for Quality Assurance in General and Further Education and Training). Thus, most independent schools write the state examination of the IEB, although independent schools may write international examinations - e.g. Cambridge examinations [O-levels and A-levels] (ISASA, 2013).

The South African Schools Act (Act 84 of 1996) recognises two broad categories of schools - public and independent (Hofmeyr \& Lee, 2002). An independent school has the freedom to choose which examining body's examination it wants its learners to write, as long as the examining body is recognised by Umalusi. Many independent schools in South Africa write the National Senior Certificate offered by either the state or that of the National Senior Certificate as offered by the IEB (Anon, 2011a). Public schools educate $85.7 \%$ and independent educational institutions cater for $2.2 \%$ of the country's learners (Anon, 2007/08). Many independent schools also follow the NCS and some write the National Senior Certificate examinations as offered by the government, whereas other independent schools follow the NCS but write the examinations of the Independent Examinations Board (IEB) (Berger, Bowie \& Nyaumwe, 2010).

\section{AIM}

In the light hereof, the aim of this article is to reflect on those crucial qualities associated with education which are pertinent for the purposes of the present article and which include resources at schools, funding, the role of politics in schools, management and leadership, and work ethics by discussing the impact of these on public and independent schools writing the National Senior Certificate final school-leaving examination. 


\section{METHOD}

This purpose will be achieved by means of a narrative discussion. The impact of quality education of public and independent schools writing the National Senior Certificate will be analysed and discussed in order to determine and recommend good practices for quality education. The databases used were EBSCO, Sabinet online and various newspapers. The keywords included: Umalusi, standardisation, Grade 12, IEB and independent schools.

\section{HISTORICAL DEVELOPMENT OF EXAMINATION BODIES IN SOUTH AFRICA}

Prior to reflection on the roles and impact of public and independent schools in South Africa, it is deemed essential to reflect on the historical development of the various examination bodies that led to and influenced the establishment of Umalusi and the IEB. These will include the JMB (Joint Matriculation Board), SAFCERT (the South African Certification Council), a discussion of the impact of the NQF (National Qualification Framework), Umalusi, and the IEB.

\subsection{JMB (Joint Matriculation Board)}

The JMB was instituted by the Act on Universities, No. 61 of 1955 . The purpose was to lay down requirements for exemption from the matriculation examination and to monitor their implementation regarding the admission to a university (Muller, 2004). Before 1994, provincial education departments set their own papers with the JMB ensuring "equal standards." That role was subsequently assumed by the SAFCERT (South African Certification Council), then by GENFETQA (the General and Further Education and Training Quality Assurance body) and later still by Umalusi (Anon, 2010).

During the previous dispensation (prior to 1994), schools had a choice of which Grade 12 examination they wanted to write - whether a national, provincial, and, in certain selected schools of high standard, the school was allowed to set the Grade 12 examination paper for selected subjects. The number of independent schools writing the JMB steadily decreased as schools opted to write the examinations of the provinces. After 1978, the JMB numbers increased again, especially those of independent candidates. This growth was largely a consequence of the political unrest impacting on education that marked the period. However, the entries decreased again after 1984. This decline was exacerbated by rumours that the JMB examinations were to be phased out with a certification council being planned to take its place (Anon, 2010).

Universities also had a sectoral interest in university entrance quality and it was this interest that the JMB served (Muller, 2004). In other words, the JMB was effectively a higher education sectoral quality assurance body which, in the absence of any other quality assurance body for the schooling system and in the absence of any other systemic assessment mechanism, effectively became the horse that simultaneously pulled both the assessment and quality assurance cart of the schooling system (Muller, 2004). The result was a closely monitored matriculation exemption standard. The resultant credibility gap between matriculation and the non-exemption Senior Certificate was a reason for the establishment in 1986 of SAFCERT (the South African Certification Council) (Muller, 2004).

\subsection{SAFCERT}

The role of SAFCERT was to ensure that certificates issued by the JMB at an exit point from the system represented the same standard of education and examining. Therefore, the main purposes of SAFCERT were to (Muller, 2004) 1) provide for control over the norms and standards of subject matter and examinations; 2) issue certificates at exit points from school, technical colleges, and non-formal education; and 3) provide for the conducting of common examinations. Thus, SAFCERT became a certification and quality assurance body.

After the establishment of SAQA (the South African Quality Assurance body) and the NQF (National Qualifications Framework) with its various bands in education and training, SAFCERT began to orient its vision and functions from externally validating examinations and issuing certificates to a more comprehensive quality assurance role. This transformational trajectory was aimed at fulfilling new roles of quality assurance for the GET (General Education and Training) and FET (Further Education and Training) (Muller, 2004). 
However, before SAFCERT could assume these new responsibilities, legislation had to be passed to enable the establishment of a GENFETQA (General and Further Education and Training Quality Assurance body). The GENFEQA Assurance Act (No. 58 of 2001), provided the legislative framework for the establishment of Umalusi. In June 2002, Umalusi took up the quality assurance and certification responsibilities of SAFCERT together with other responsibilities.

\subsection{NQF (National Qualifications Framework)}

In 1988, the idea of establishing the NQF was, for the first time, seriously cultivated by trade unions and business in South Africa. A concept that originated in Australia and New Zealand especially, but also in the UK and Scotland, focused on the notion of establishing "national standards" which would be transparent, widely agreed descriptions of the knowledge, skills, and values required at particular levels, and specifying the assessment criteria by which it could be shown that individuals had reached specific levels of achievement or competence (Anon, 2010). The new thinking drew on emerging trends in the use of assessment and certification to lead the way to education and training that was relevant to a new world, but also just and transparent, and that was pedagogically rich while promoting efficiency (Anon, 2010).

\subsection{Umalusi}

Umalusi was established in 1994 when the newly-elected democratic government abolished all the old ways that were systemically linked with apartheid and introduced new policies (Du Plessis, 2009). This independent quality assurance body is guided in terms of the GENFETQA Act (No. 58 of 2001) and whose main purpose is to assure the quality of the assessment processes leading to the issuing of certificates to learners at Grade 12 level (Coetzee \& Johl, 2008).

Umalusi is currently responsible for 1) evaluations of qualifications and curricula to ensure that they are of the expected standard; 2) moderating assessments to ensure that it is fair, valid and reliable; 3) conducting research to ensure educational quality; 4) accreditation of educational and assessment providers; and 5) verification of the authenticity of certificates.

\subsection{IEB (Independent Examination Board)}

In the late 1980's when the JMB announced that it would cease to function as an examining authority in South Africa, a number of principals at independent schools took the initiative of establishing an organisation that would assume the examining function of the JMB. The IEB was then born as an organisation of civil society, standing in opposition to a system that, at the time, was democratically and educationally unacceptable (Soudien, 2012).

The IEB offers external assessment in accordance with legislation and Umalusi directives for schools registered from Grades 9 to 12, at which point successful Grade 12 learners are awarded the National Senior Certificate. It started to operate in 1989 and the IEB remains committed to building a quality education system for all South Africans (Oberholzer, 2010). The IEB was given accreditation by Umalusi in 2005 for school examinations at the levels of Grades 9 and 12 (Oberholzer, 2010).

\section{A REFLECTION ON AND DISCUSSION OF PUBLIC - AND INDEPENDENT SCHOOLS}

This section will discuss the logistical orientation of public and independent schools as well as indicators that influence the Grade 12 examination.

\subsection{Logistical Orientation of Public and Independent Schools}

\subsubsection{Numbers of Learners at Public and Independent Schools}

South Africa has 12.3 million learners from Grades R to 12 (Anon, 2007/08). Public schools writing the National Senior Certificate have an estimated school cohort of more than 600,000 candidates and the IEB has fewer 
than 10,000 candidates in 183 schools in 2012 (Sapa, 2013). The majority of independent schools write the National Senior Certificate as offered by the Department of Basic Education (DBE), but 172 out of 500 schools wrote the IEB examinations based on the NCS in 2011 (Hofmeyr \& Oberholzer, 2011a; Gravett \& Godsell, 2011). Although there is a large difference in numbers, the independent school sector should be seen as complementary to public education and can therefore serve as a valuable partner of government in developing skills, building social capital, and reducing inequalities (Jackson, 2008).

\subsubsection{Differentiation Based on Race}

There is the common notion that independent schools are for the elite and are mostly white. In reality, 73\% of learners in independent schools are black and come from across the socio-economic sector, including informal settlements and rural areas (Hofmeyr \& Oberholzer, 2011b; Lee in Davids, 2011). It is also worthwhile noting that $56 \%$ of schools established in the past 15 years are independent and $60 \%$ of all children attending these schools are from previously disadvantaged communities, including families in the informal economy (Immelman, 2011; Jackson, 2008).

\subsubsection{Resources at Schools}

Many people tend to believe that the only way for children in poor countries to receive a basic education is through larger education budgets or more resources at public schools (Immelman, 2011). On the contrary, a study by the Centre for Development and Enterprise (CDE) found that independent schools serve some of the poorest people in the world and the outcomes of these schools are on par with public schools at far lower cost and with fewer facilities (Tshabalale, 2006). It is argued by some that a lack of resources contributes to a low success rate (Hofmeyr $\&$ Oberholzer, 2011b). In reality, there are schools with minimal resources that achieve excellent results (Hofmeyr \& Oberholzer, 2011b; Gravett \& Godsell, 2011). It goes without saying that children from rural schools can also reach great heights, but such an achievement requires the presence of dedicated teachers (Jackson, 2008; Anon, 2011a). Parents of children attending independent schools in rural areas are unable to pay high fees. These schools lack the resources and teachers' salaries are only a fraction of their public school counterparts, yet some of these schools outperform public schools in South Africa (Immelman, 2011).

\subsubsection{Diversification}

Furthermore, the state examination serves a very heterogeneous, diverse cohort of candidates with a broad range of ability levels, many with illiterate parents. By contrast, the IEB candidates are more homogeneous as they generally come from middle-class families across the low to upper middle-class spectrum, although there are also a growing number of independent schools in rural areas (Hofmeyr \& Oberholzer, 2011a). Some of these independent schools are religious-based and more parents choose to send their children to these schools because of the discipline and structure, as well as the fact that religion is not taught in public schools (Lee in Davids, 2011; Roos, 2004).

\subsubsection{Funding of Public - and Independent Schools}

The funding of public schools revolves around the following three elements (Roos, 2004): 1) State-based posts for both educators and non-educators, 2) the provision of a monetary state subsidy in terms of the National Norms and Standards for the funding of schools, and 3) the right of the School Governing Body (with support of the parents) to implement the payment of compulsory school fees by parents (Immelman, 2011; Roos, 2004).

Independent schools are mainly independently funded, with only a few receiving a partial state subsidy (Immelman, 2011; Anon, 2007/08). These schools need to remunerate their staff component and parents are responsible for school fees that may vary but are usually far higher than those of public schools (Anon, 2007/08). On the other hand, it is argued that the growing low to medium-fee schools in the independent sector have also doubled from 2002-2011 from 121 to 288 schools (Lee in Davids, 2011). Research by the Centre for Development and Enterprise and the International Finance Corporation shows that most independent schools in South Africa charge low to mid-level fees and that only $14 \%$ of the sector comprise high-fee schools (Hofmeyr \& Oberholzer, 2011b). 


\subsubsection{Politics in Schools}

Fourteen years ago, Jansen (1999) predicted that OBE would fail, not because politicians and bureaucrats are misinformed about conditions in South African schooling, but because the education policy was being driven by political imperatives that had little to do with the realities of classroom life. Furthermore, political violence in South Africa has often led to high levels of intolerance and subsequently too much violence within the education system (Ngqela \& Lewis, 2012). The Grade 12 results became a political football for politicians in public schools (Jansen in Phakathi, 2012).

SADTU (the South African Democratic Teachers' Union), with an overall majority in membership of 240,000 teachers, has had a highly detrimental effect on education in the country. In 2010, SADTU threatened a total shutdown of all public services, including essential services, if the government did not yield to its wage demand (Mbanjawa, 2010). The DA's (the Democratic Alliance) leader, Helen Zille, strongly stated that SADTU and COSATU (Congress of South African Trade Unions) were destroying children's future as strikes at the beginning of 2012 to protest against redeployment of teachers denied learners their right to education (Wilson, 2012). In this process, unions were being used as a launching pad for political careers (as suggested earlier), rather than as a means to resolve disputes of workers (Wilson, 2012). Quite ironically, President Zuma gave SADTU a benediction when he extended his appreciation to this union in his 2012 State of the Nation address (Komsana, 2012).

In light of the above, it is also not a surprise that the government has persistently been vulnerable to exploitation and corruption which includes nepotism, the fraudulent awarding of tenders, and the circumvention of procurement processes (Oppelt, 2012). This leads to distrust that has an overflow to the education culture, and even the ANC educationalist and architect of OBE, Graeme Bloch, admitted that the politically motivated implementation of OBE had been a mistake (Du Plessis, 2009).

It also needs to be mentioned that 2012 was a disastrous year for the reputation of the Minister of Basic Education, Angie Motshega, and many expected her to be fired for the textbook scandal in the Limpopo Province. Instead, the Grade 12 results provided the kind of relief she needed and, even before the results were declared to be valid and fair by Umalusi, the minister told the media that the pass rate would go up (Jansen, 2013a). It will go up again and again because she says so and, before long, she will declare that her goal of $75 \%$ had been reached before the set date of 2014 (Jansen, 2013a).

In contrast to the public sector, involving the state schools, independent education is hardly affected by political influences such as strikes, violence and union interference in schools, as these schools are well-ordered with organised teachers (SAPA, 2011). Independent schools attract and retain teachers because of their positive ethos and learning environment, despite the fact that many independent schools teachers' remuneration is less than that of public school teachers (Immelman, 2011).

\subsection{Indicators Influencing the Grade 12 Examination}

\subsubsection{Management and Leadership}

Good leadership makes a good school - there are anecdotal examples of poor black schools in squatter areas that outperform their peers, apparently because they have good leadership and committed teachers (Immelman, 2011; Tshabalale, 2006; Joffe, 2004).

Since 1994, the present government has made enormous progress in addressing the major inequities that characterised education provision in South Africa for many years, but at the same time questions are asked about the extent to which the quality of what is offered in public schools is what it should be (Roos, 2004). The researchers cannot agree more with Jansen (2013b) than that "we have reduced education to a forced-feeding system exercise that takes place before the examinations." Less demanding question papers, under-qualified markers, exam coaching, and holding back of risky candidates might be reasons for the manufactured improvement in Grade 12 results (Monama, 2012). The reality is that parents are losing confidence in the state schools and are opting to send 
their children to independent institutions as this sector showed a growth of 50\% over recent years (Davids, 2011). One should acknowledge that although there is a significant percentage of growth at independent schools, learnerwise it is on a small scale when compared to state schools. On the other hand, the growth also does indicate that parents are losing faith in the public school sector (Roodt in Davids, 2011).

Therefore, one can confidently state that there are two main factors responsible for the growth of independent education: 1) Access to and demand for education above what the state can provide and 2) differentiated demands for alternative types and quality of education to that provided by the state (James, 1991).

Furthermore, various challenges haunt education and hamper the successful implementation of the curriculum. These include lack of educator skills, demotivation, poor salaries, increased workload, poor career progression, dissatisfaction with work policies, and job uncertainty (Anon, 2007/08).

\subsubsection{Differences in Quality Teaching at Public and Independent Schools}

As the independent school sector is relatively small, such schools tend to respond to change more quickly than public schools (Jackson, 2008). Therefore, they can implement new policies and programmes - e.g., the policy on inclusivity, the first integrated studies approach, teacher learnerships, and self-evaluation programmes - more easily (Jackson, 2008). The CDE (Centre for Development Enterprise) also indicates that teaching quality and learner results were often better in independent schools, even with fewer resources (Tshabalale, 2006).

Assessment approaches of the IEB and Umalusi are different. The IEB's approach is an innovative, probing assessment which emphasises higher order thinking skills that have a positive impact on teaching and learning in the classroom (Hofmeyr \& Oberholzer, 2011b). By this means, it actively uses assessment to improve teaching and learning in the classroom which, in turn, provides learners with the attitudes, skills and knowledge necessary for success in higher education. In contrast, the amount of time during the year that teachers actually teach learners at public schools indicates that the latter only teach $60 \%$ of the lessons they were scheduled to teach (Jansen, 2013a).

The balance in the IEB examinations tends towards the high end of cognitive demand (Hofmeyr \& Oberholzer, 2011a). Thus, the state examinations have to achieve a different balance of low-end and high-end thinking skills to cater for the broader spread of abilities in a massified education system (Hofmeyr \& Oberholzer, 2011a). A higher pass mark might raise achievement and aspiration levels for learners but will not solve quality problems in the system, such as poor teaching, poor management, resource backlogs, and poverty (Bloch in Phakathi, 2012). Independent schools writing the IEB examination are achieving consistently good results based on a combination of factors which include support for teachers, good school leadership, and a supportive environment for learners (SAPA, 2011; Anon, 2011b).

\subsubsection{Benchmarking Tests}

Another factor that influences quality in schools writing the NCS is benchmark testing. In this regard, the Third International Mathematics and Science Study (TIMSS) was conducted in 1995 (Howie, 2004). In TIMSS, the performance of the South African learners was significantly below learners in the other 40 participating countries. The main purpose of TIMSS was to enable countries to determine whether they were internationally competitive, to examine the variety of best practices in successful schools, and, finally, to establish world-wide benchmarks for setting and evaluating goals in Mathematics and Science (Nair, 2003).

TIMSS was repeated in 1998/1999 and South African learners achieved an average of 275 points out of 800, whilst the international average was 500 (Howie, 2004). Once again, South African learners performed significantly worse than those from other participating countries. The tests indicated that learners who spoke English or Afrikaans at home tended to achieve higher scores in Mathematics (Howie, 2004). In contrast, children from homes where African languages were used were more likely to achieve lower scores. Also, learners from poor homes were less likely to achieve high scores in Mathematics as opposed to those from wealthier families. When looking at these results, it becomes clear that South Africa's education system cannot compete with standards in other countries. TIMMS outcomes of 2011 indicated that South African children perform way below their counterparts in other developing countries in Science, Mathematics and Literacy (Jansen, 2013a). 
Also, the recent World Economic Forum's annual report on financial development placed South Africa last in a survey of 62 countries (including poor states, such as Bangladesh, Kenya, Colombia and Tanzania) in the quality of Science and Maths education (Jansen, 2013a).

During the Grade 12 examination in 2012, learners scored an average of 54\% for Mathematics (Nkosi \& Monama, 2013). Interestingly, benchmarks for Maths in 2011 for Grade 9 in the Western Cape (the second best of the nine provinces in South Africa according to the 2012 Grade 12 results) indicated that learners' raw mark was 13.9\% (Heyl, 2013). Despite this reality, the Minister of Basic Education maintains that the current curriculum is of a higher standard than before (Nkosi \& Monama, 2013).

On the other hand, the UK's National Recognition Information Centre is responsible for comparing international qualifications. It was commissioned by the IEB to evaluate and the finding was that the standard of the AP Maths (Advanced Programme in Mathematics) set for South African learners compared favourably with the UK (Govender, 2012). Since the inception of the APM in 2008, the number of student participation had risen from 761 to 1,067 learners, indicating a $40 \%$ increase (Petersen, 2011). In comparison, the Maths paper written by state schools is much simpler and the average learner at state schools will not be able to cope with the difficulty level of AP Maths (Govender, 2012). Furthermore, in 2008 independent schools educated only 4\% of South Africa's learners, but they produced about $10 \%$ of all black matriculants with higher grade passes in Mathematics and Science (Jackson, 2008).

The IEB also provides schools with international benchmarking tests with the assistance of the Australian Council for Education Research. These tests focus on language and Mathematics and begin at Grade 3. Most importantly, feedback from Australia is critical and assists in preparing children to improve (Oberholzer in Hawker, 2012). Education specialists also agree that with external benchmarking, teacher quality and parent involvement are influential factors in learners' success at independent schools (Hawker, 2012). Education analysts suggest that the best teachers, smaller classes, extra lessons, a good work ethic and consistent international benchmarking put IEB schools at the top of the list when analysing Grade 12 results (Hawker, 2012).

\subsubsection{Moderation and Standardization of Grade 12 Examination Papers}

For qualifications to be certified by Umalusi, learners need to achieve prescribed outcomes to a standard maintained throughout the country. These learner achievements are measured by individual assessors against criteria that are linked to the outcomes of the learning programme. To ensure that standards are maintained, a process must be in place to benchmark external standards; this process is referred to as moderation (IEB, 2004).

Before the election of the democratic government in the period since 1994, it was the custom that the then four provinces nominated one or two examiners from their existing panels for the national papers and from these nominations the National Department of Education then selected the best qualified examiners. It was then the task of the External Moderator of Umalusi, who administers the papers of all nine provinces, to provide direction to the appointment of the best examiners based on the ability of each examiner and therefore assuring the quality of the examination process (Coetzee \& Johl, 2008). However, in 2003 an open invitation was extended nationally to all teachers who considered themselves qualified to set the National Senior Certificate examination papers and, in the process, sidestepping the External Moderator who no longer had any role in the selection of the panels. Thus, the current appointment process of examiners lacks the necessary guarantees that the best examiners are appointed (Coetzee \& Johl, 2008).

The results of independent and public schools offering the NCS are benchmarked by Umalusi (Rakometsi, 2012). As such, standardisation is the last step in the Grade 12 examination to make final adjustments to the Grade 12 results and is a key element of most certification systems anywhere in the world to ensure that no one is disadvantaged if an examination is harder than usual in the year of the specific examination (Taylor, 2011).

According to Umalusi (2011), this is an essential tool to correct fluctuations in performance that are the result of factors within the examination process rather than the knowledge and abilities of candidates and which, could unfairly have an impact on candidates. Jansen (in Potgieter, 2010) argues that they make adjustments in 
smaller subjects which would allow thousands more learners to pass Grade 12. Also, if there is an opportunity to change raw exam marks every year, the public does not have any guarantee that the process is not used for political purposes, such as increasing key indicators, to make the government look good (Jansen, 2013a). Findings published in Nova (2005) confirmed these speculations and stated that a statistical manipulation of marks was introduced to ensure a pass rate more aligned with the previous years' results.

It needs to be mentioned that standardisation at public schools also includes the process of external moderation of exam papers as well as the process of review of results against the historical performance of candidates (Oberholzer, 2011). Therefore Umalusi uses this process to correct problems at a late stage which makes it very difficult for anyone to understand what the candidates actually achieved. There is also a debate as to whether standardisation, as practised by Umalusi, is a common international practice, and the general feeling is that results and the standardisation process should be more transparent (Tlhabi, 2011). Thus, standardisation of Grade 12 results is creating a barrier between original results and adjusted results, therefore contributing to major discrepancies in the context of the reliability of the schooling system (Naidoo, 2004; Oberholzer, 2011).

There is also the possibility that during the standardisation process, efficiency is sacrificed as the public only recognises the pass rate as a valid indicator of quality and the state receives the credit (Taylor, 2011).

\subsubsection{Differences in Pass Rate between Public and Independent Schools}

In order to enhance the composite role and impact of the National Senior Certificate in public and independent schools, it is deemed necessary to highlight the results of both these sectors from 2008 (the first year of writing the National Senior Certificate) to 2012, as well as to note the increase of the pass rate in public schools in almost all the years, except 2009 (Nkosi \& Monama, 2013). It can be seen in Table 1 that there is a significant discrepancy between the pass rate for Grade 12 learners in public and independent schools which should be questioned.

Table 1: A Comparison between the National Senior Certificate Grade 12 Results of Public - And Independent Schools Writing the IEB Examinations in South Africa (2008-2012)

\begin{tabular}{|c|c|c|}
\hline Year & Public Schools Pass Rate Of GR 12 & Independent Schools Pass Rate Of GR 12 \\
\hline 2008 & $62,6 \%$ & $97,01 \%$ \\
\hline 2009 & $60,6 \%$ & $97,42 \%$ \\
\hline 2010 & $67,8 \%$ & $98,38 \%$ \\
\hline 2011 & $70,2 \%$ & $98,15 \%$ \\
\hline 2012 & $73,9 \%$ & $98,2 \%$ \\
\hline
\end{tabular}

With regard to public schools, the almost ongoing increase of Grade 12 results is unrealistic as there were many curriculum changes from 2008 to 2012 (Monama, 2012). One should also keep in mind that the Grade 12 pass rate, which was as low as $40 \%$ in the late 90 's, continues to improve, reaching $73.9 \%$ in 2012 , despite the fact that illiteracy rates are $24 \%$ for adults over 15 years of age (Anon, 2007/08). Furthermore, the year 2011 saw a severe three-week strike in education and 2012 had to deal with the textbook scandal in the Limpopo Province where textbooks were not delivered to schools on time (Monama, 2012). Two provinces, Limpopo and Mpumalanga were also placed under administration and, in the light hereof, it could be assumed that it is highly unlikely to reach a pass rate of $73.9 \%$ in 2012 (Jansen, 2013a).

The results of independent schools writing the IEB examinations are higher and, moreover, there is the important fact that most of these learners pass and qualify for degree studies - e.g., in 2011, the pass rate for IEB candidates was $98.15 \%$ and those who qualified for degree studies constituted $81.67 \%$. In 2010, the pass rate was $98.38 \%$ (Evans, 2012).

\section{CONCLUSION}

All learners in South Africa are entitled to quality education which will strengthen their chances to enter the workforce. Although many discrepancies exist between public and independent schools, as stated, it is strongly 
suggested that good education practices, as implemented by the latter, should be followed. It is also important to note that the radical differences in quality education within the two sectors cannot be attributed to smaller numbers, but rather to excellent work ethics, good disciplinary practices, and a-political attitude. It was interesting to note that these learners come from poor backgrounds as well, are not mostly white, and do not have highly-resourced schools.

Thus, education in South Africa is facing a severe crisis and, as Jansen (2013b) states, "Neither Hendrik Verwoerd (the architect of apartheid) nor the current minister of education believes that a black child can excel in Mathematics." Although the state is acknowledging the challenges in the education system, South Africa is experiencing a tsunami in education, and the state needs to address the downward spiral and focus on quality education, which includes high cognitive standards of assessment, effective management, good work ethos, and apolitical schools, where a rating system will pinpoint areas for improvement.

\section{RECOMMENDATIONS}

After reflecting on the impact that public and independent schools have on quality education and the outcome of school education, as reflected in Grade 12 results, the following recommendations are made:

- Independent schools are complementary to public education and, as a partner of government public schools, should focus on the positive attributes provided by the training of independent schools on skills development and building on social capital.

- It is acknowledged that resources at schools are essential, but this should also not necessarily hinder quality education as there are schools with minimal resources and with excellent results. The government should provide special training and support to teachers, learners and parents in these areas in order to motivate quality education.

- $\quad$ Political influences in education, such as strikes, wage demands, union interference and political violence, are ongoing stumbling blocks that further cripple education. As these influences are not visible, to any extent, at independent schools, it is strongly recommended that steps from the government should be put in place to rid education of any political interaction.

- $\quad$ Good leadership makes a good school and a good school has committed teachers. Performance agreements for principals and teachers should be closely monitored in order to discipline inappropriate performance at schools.

- The over-emphasis on Grade 12 results for both sectors should be revised. It is recommended that benchmark testing should be conducted annually at all the exit levels, viz., Grades 3, 6, 9 and 12 at selected schools in rural, deep-rural and urban areas in all nine provinces in South Africa. It is recommended that benchmark testing should be conducted annually at all the exit levels, viz., Grades 3, 6, 9 and 12, at selected schools in rural, deep-rural, and urban areas in all nine provinces in South Africa. This should be done to ensure that quality education and the outcomes per phase have been met.

- Research on the purpose, impact, and effectiveness of standardization of Grade 12 results should be conducted at an international level in order to determine the actual level per subject of Grade 12 results in order to standardize future results on a benchmark that will depict a true reflection of the abilities of Grade 12 learners.

- $\quad$ A grading system should be introduced based on outcomes at schools and on benchmarking testing. This should not be according to income, area, or any other measure, except quality education offered at a school. A grading system should be applicable for primary and secondary schools.

\section{AUTHOR INFORMATION}

Nelda Mouton is an educationalist with extensive experience on education issues from pre-school up to Grade 12. Her focus area was English and as head of Curriculum Development in this area as well, she served on various committees and travelled abroad to observe curriculum developments in Europe. She was part of the process of Curriculum Development in South Africa and was appointed the education specialist for the Head of Department of the North-West province. Apart from a $\mathrm{PhD}$ in English, she also has a $\mathrm{PhD}$ in Education Management. She is appointed as a Manager in Academic Services at the North-West University and deals with all aspects of student 
admissions at the tertiary level. Furthermore, she is actively involved in research, peer reviews and editing of theses and dissertations. E-mail: 10516387@nwu.ac.za (Corresponding author)

Gert L. Strydom is an emeritus-professor (Potchefstroom Campus) and an extraordinary professor (Mafikeng Campus) of the North-West University South Africa; he is also visiting professor at the University of Venda. He received his BA, Hons BA, MA and DPhil from the Potchefstroom University, all three postgraduate degrees with distinction. He is also the holder of an honorary doctorate from the North-West University for his dedicated work in the academic environment. Professor Strydom is doing research over a broad spectrum of disciplines with the main research field health science; the health discipline Biokinetics, registered as the profession biokinetics/clinical exercise physiologist with the Health Professional Council of South Africa, originated from his research and creative leadership. He is affectionately called the "South African Father of Biokinetics." He published extensively in peer reviewed and accredited journals, locally and internationally, and acted as the sole as well as co-author for many books. He was promoter for many doctoral theses and masters dissertations as well as other research projects. He is still very active in this domain. Professor Strydom delivered many presentations on scientific conferences in South Africa and abroad. E-mail: 10172521@nwu.ac.za

\section{REFERENCES}

1. Anon. (2007/08). Education. South Africa Business Guidebook, 2007/08, 115-116.

2. Anon. (2010, July 30). Assessment matters. Star, p. 1.

3. $\quad$ Anon. (2011a, January 6). Teacher quality a big difference. The Citizen, p. 12.

4. $\quad$ Anon. (2011b, May 26). Spotting trouble. Mail and Guardian, p. 2.

5. Berger, M., Bowie, L., \& Nyaumwe, L. (2010). Taxonomy matters: Cognitive levels and types of Mathematical activities in Mathematics examinations. Pythagoras, 71, 30-40.

6. Coetzee, W., \& Johl, R. (2008). The role of moderation in the National Senior Certificate examination. Journal for Language Teaching, 42(2), 26-41.

7. Davids, N. (2011, January 18). Parents disillusioned with most government schools. The Times, p. 2.

8. Du Plessis, T. (2009, October 2). Als was toe nie so sleg. Beeld, p. 12.

9. $\quad$ Evans, S. (2012, January 4). School gets 100. Diamond Fields Advertiser, p. 2.

10. General and Further Education and Quality Assurance Act. (2001). Act 58. Pretoria: Government Printers.

11. Govender, P. (2012, December 30). Maths boffins buck trend. Sunday Times, p. 10.

12. Gravett, S., \& Godsell, G. (2011, January 20). Independent good; Public not so bad. Mail and Guardian, p. 39.

13. Harley, K., \& Wedekind, V. (2004). Political change, curriculum change and social formation, 1990 to 2002. In L. Chisholm (Ed.), Changing class: Education and social change in post-apartheid South Africa (pp. 195-220). Cape Town: Compress.

14. Hawker, D. (2012, January 8). Time to fight for quality education, Sunday Independent, p. 5-6.

15. Heyl, G. (2013, January 14). KykNet. eNews.

16. Hofmeyr, J., \& Lee, S. (2002). Demand for independent education in South Africa: Schooling and higher education. Perspectives in Education, 20(4), 77-85.

17. Hofmeyr, J., \& Oberholzer, A. (2011a, February 2). Meaning partners in education. Mail and Guardian, p. 50.

18. Hofmeyr, J., \& Oberholzer, A. (2011b). Busting the race myths about independent education. Pretoria News, p. 7.

19. Howie, S. (2004). A national assessment in Mathematics within an international comparative assessment. Perspectives in Education, 22(2), 149-161.

20. IEB. (2004). Course for moderation in education. Pretoria.

21. Immelman, J. (2011, January 15). 60\% of private school pupils from poor homes. The EP Herald, p. 15.

22. ISASA. (2013). Examinations. Retrieved from http://www.isasa.org/content/view/2013/07/17

23. Jackson, D. (2008, October 2). Lessons from private schools. Mail and Guardian. p. 46.

24. James, E. (1991). Independent finance and management of education in developing countries: Major policy and research issues. Paris: UNESCO/IEEP.

25. Jansen, J. (1999). Why outcomes-based education will fail: an elaboration. In Education in South Africa (pp. 145-146). Cape Town: Juta. 
26. Jansen, J. (2013a). Education crisis a threat to democracy. Retrieved from http://www.polity.org.za/article/education/2013/01/04

27. Jansen, J. (2013b, January, 6). Our matric results and schooling: Two ways of doing the Maths. Sunday Times Review, p. 1.

28. Joffe, H. (2004, June 22). Skills boost, not money alone, a must to bridge education gap. Business Day, p. 12.

29. Komsana, K. (2012, April 18). Reckless act reflects culture of impunity. Daily Dispatch, p. 11.

30. Malada, B. (2010, September 19). We ignore proper education at our peril. Sunday Tribune, p. 22.

31. Maluleka, S. (2011, August 10). Curriculum: Back to the blackboard. Daily News, p. 3.

32. Matoti, S. N. (2010). The unheard voices of educators: perceptions of educators about the state of education in South Africa. South African Journal of Higher Education, 24(4), 568-584.

33. Mbanjawa, M. (2010, August 19). It's "war" on public services: SADTU. Daily News. p.1.

34. Monama, T. (2012, October 3). Matrics are going to get the marks that they deserve. Sowetan, p. 6.

35. Mouton, N., Louw, G. P., \& Strydom, G. L. (2012). A historical analysis of the post-apartheid dispensation education in South Africa (1994-2011). International Business and Economics Research Journal, 11(11), 1211-1221.

36. Muller, J. (2004). Assessment, qualifications and the NQF in South African Schooling. In Chrisholm, L, (Ed.). Changing class: Education and social change in post-apartheid South Africa (pp. 221-246). Cape Town: Compress.

37. Naidoo, S. (2004, January 7). Maths and science results adjusted upwards. Business Day, p. 3.

38. Nair, P. A. P. (2003). Can prior learning experience serve as a catalyst in the paradigm shift from traditional teaching methodology to outcomes-based educational practice?: Perspectives on higher education. South African Journal of Higher Education, 17(2), 68-78.

39. Nel, C., \& Kistner, L. (2009). The National Senior Certificate: Implications for access to higher education. South African Journal of Higher Education, 23(5), 953-973.

40. Nkosi, N., \& Monama, T. (2013, January 3). Top marks for matrics. Sowetan, p. 2.

41. Ngqela, N., \& Lewis, A. (2012). Exploring adolescent learners' experiences of school violence in a township high school. Child Abuse Research: A South African Journal, 13(1), 87-97.

42. Nova. (2005, December 30). Only 17\% of matrics of class 2005 passed. Academic Press, p. 5.

43. Oberholzer, A. (2010, July 30). Message from the CEO of the IEB. Star, p.1.

44. Oberholzer, A. (2011, February 16). Adjusting pupils' marks can be practical necessity. Daily Dispatch, p. 7.

45. Oppelt, P. (2012, July 29). Apartheid is to blame. Sunday Times, p. 5.

46. Petersen, L. (2011, January 4). Improvement in matric pass rate. The Citizen, p. 3.

47. Phakathi, B. (2012, April 19). Umalusi defends 30\% matric pass rate. Business Day, p. 1.

48. $\quad$ Potgieter, M. (2010, February 19). Skoksyfers oor gr. 6 leerders. Burger, p. 1.

49. Rakometsi, M. (2012, February 5). Don’t twist Umalusi figures. City Press, p. 28.

50. Roos, C. (2004). Privatisation and funding of education. Perspectives in Education, 23(30), $125-134$.

51. South African Schools Act. (1996). Act 84 of 1996. Pretoria: Government Printers.

52. Soudien, C. (2012). Chairman's message 2012. Annual Report, p. 2.

53. South African Press Association (SAPA). (2011, January, 5). Educationists don't expect dramatic shift. Star, p. 3.

54. South African Press Association (SAPA. (2013). IEB boasts 98.2\% matric exam pass rate. Retrieved from http://mg.co.za/article/2013/06/17

55. Spreen, C. A., \& Vally, S. (2010). Outcomes-based education and its (dis)contents: Learner-centred pedagogy and the education crisis in South Africa. Southern African Review of Education with Education with Production, 16(1), 39-58.

56. Taylor, N. (2011, March 17). Matric: Quality vs quantity. Mail and Guardian, p. 43.

57. Tlhabi, R. (2011, February 25). Public's trust in Umalusi wiped out. Sowetan, p. 19.

58. Tshabalale, S. (2006, February 1). Private schools - the answer to a better education? Enterprise, p. 40.

59. Umalusi Report. (2011). Why Umalusi standardises results, and how. Umalusi: Pretoria.

60. Wikipedia. (2013). Independent Examinations Board. Retrieved from http://en.wikipedia.org/wiki/Independent_Examinations_Board/2013/06/17

61. Wilson, G. (2012, March 22). Zille leads PE protest. The Herald, p. 1. 